reasons, the United States has become relatively complacent in maintaining its higher education advantage.

Author's note: This article is adopted from the author's new book, The Conditions for Admissions: Access, Equity, and the Social Contract of Public Universities.

\section{Where Are Global Leaders Educated?}

\section{Moosung Lee}

Moosung Lee is a PhD candidate in the Department of Educational Policy and Administration at the University of Minnesota. Address: 269 Appleby Hall, 128 Pleasant Street SE, Minneapolis, MN 55455, USA. E-mail: leex2125@umn.edu.

$\mathrm{T}$ The increasing global influence of international organizations creates some curiosity about the educational backgrounds of top officials in leading international organizations. This article explores which universities are regarded or preferred as world-class universities by recruiters in the leading international organizations. Data were obtained from the Year Book of International Organizations (2005-2006) and Who's Who in International Organizations (2006), which include I5,354 leading organizations ranging from United Nations agencies to virtually every type of international organization. As such, the educational backgrounds of 2,563 high-ranking officials were identified-encompassing secretaries-general, directors-general, deputy and assistant directors-general, and department heads. Included in this sample were top officials holding one or more of the higher education degrees (i.e., bachelor's, master's, and doctoral).

\section{Education of Global Leaders}

The majority of these global leaders were trained at Western universities. Of the 2,563 high-ranking officials, 88.5 percent of them earned at least one higher education degree at Western universities. In particular, almost half of these alma maters are located in two English-speaking countries: the United States, 27.4 percent, and the United Kingdom, I8.8 percent. These national figures to some extent reflect the percentage of global elite universities located in these two nations, as suggested by the rankings of the Times Higher Education Supplement (THES) and Shanghai Jiao Tong University (SJTU). For example, the 2005 THES ranking reveals that 26.5 percent of the top 200 universities were located in the United States, which is consistent with the percentage of the top officials educated in the United States (27.4\% of the top 2,563 officials). Also, I6 per- cent of the top 200 universities were located in the United Kingdom according to the 2005 SJTU data-similar to the percentage of the top officials educated in the United Kingdom (I8.8\%). The prestigious universities in those two countries served as the major source for top officials. A striking II.7 percent of the 2,563 officials were cultivated by only four universities: Harvard (4\%), Oxford (3.4\%), Cambridge (2.5\%), and Yale (т.8\%).

Another distinctive feature was that 4I percent of top officials turned out to be educated in western European countries other than in the United Kingdom. The institutions where 29.5 percent of top officials were educated were located in four European countries: France (II.5\%), Belgium (8.8\%), Germany (4.9\%), and the Netherlands (4.3\%). These top officials were educated in I9 cities in countries where several well-known universities are clustered-for example, Paris (e.g., Paris I to Paris XIII, and École Normale Supérieure) and Brussels (e.g., Université Libre de Bruxelles and Université Catholique de Louvain).

The leading position of Western universities in supplying officials for these international bodies means that many nonWestern universities were thus marginalized in terms of shaping the membership structure of these organizations. Only II.5 percent of the top officials were educated at universities in Asia Pacific (6.3\%), Latin America (2.I\%), eastern Europe (1.8\%), and Africa (I.3\%). Even academically well-known universities in the Asia Pacific region lagged far behind their Western counterparts in generating global leaders. Only 6.3 percent of the top officials were educated at universities in the Asia Pacific region, where 5I universities out of the top 200 (25.5\%) were located, according to THES. More specifically, while I7 Australian universities were ranked in top 200 by the THES, only 0.7 percent of the top officials were educated at Australian universities.

The leading position of Western universities in supplying officials for these international bodies means that many non-Western universities were thus marginalized

\section{Advantage of Geographic Location}

An investigation confirms that this hiring disparity cannot be explained by school rankings. Located in four western European countries, the universities that are producing many global leaders were generally ranked lower than certain wellknown universities in the Asia Pacific region and even North America (e.g., Tokyo, Beijing, Melbourne, Australia National University, Michigan, and Toronto). For example, 8.8 percent of top officials were educated in Belgian universities, but only four Belgian universities were ranked among the top 200 
schools by both the THES and the SJTU ranking tables in 2005. Moreover, there were no Belgian universities listed in SJTU's top Iо०. By contrast, only I.3 percent of top officials were cultivated in Canadian universities, despite the fact that, respectively, 8 and I2 Canadian universities were ranked in the top 200 by the THES and SJTU.

The advantage these western European universities enjoy appears related to geography. A considerable number of principal secretariats for international organizations are located in western Europe. Specifically, 60.2 percent of 2I,6I2 principal secretariats were located in western Europe. Of the principal secretariats, 32.3 percent were located in the four western European countries already mentioned-France (II.4\%), Belgium (I4\%), Germany (3.5\%), and the Netherlands (3.4\%) where 29.5 percent of top officials were educated. By contrast, only 0.9 and 2.2 percent of the principal secretariats were located in Australia and Canada, respectively. Therefore, it can be speculated that these universities located in France, Belgium, Germany, and the Netherlands seem to be making the most of their geographical proximity to the headquarters of international organizations in supplying human resources.

It is thus reasonable to assume that non-Western voices or mindsets may often not be well heard or applied when global issues are confronted by these international bodies.

\section{POSSIBLE IM PLICATIONS}

Because of their common university backgrounds, the highranking officials in leading international organizations probably experienced a similar academic ethos and somewhat homogeneous curricula. Their ways of defining and approaching global problems are likely to have much in common. It is thus reasonable to assume that non-Western voices or mindsets may often not be well heard or applied when global issues are confronted by these international bodies. By recruiting key personnel from the same preferred universities, these international organizations are to some degree instilling particular cognitive and cultural norms.

While the common educational backgrounds may be contributing to similar worldviews among global leaders, the results of this research do not necessarily prove that global leaders are excessively homogeneous. Rather, these leaders are not likely to be monolithic in both their private and public lives as are their universities in terms of vision, orientation, modus operandi, intellectual legacy, and academic culture. Nonetheless, the results do reveal which universities are selectively appreciated, preferred, and accepted as most qualified to supply human resources for international organizations.

\section{Sustaining Oxford as World Class}

\section{David Palfreyman}

David Palfreyman is bursar and fellow in New College, Oxford University, and director of the Oxford Center for Higher Education Policy Studies. Email: www.oxcheps.new.ox.ac.uk.

Tet's be forthright in acknowledging the miniherd of eleLphants now ensconced inside the Oxford University senior common room (SCR), one in each corner and one wallowing by the sherry decanters in the middle of this elegant room. The five are labeled: "Remaining World Class," "Raising Tuition Fees," "Protecting Tutorial Teaching," "Widening Participation," and "Defending Academic Self-Governance" (the last subtitled "Keeping the Lunatics in Charge of the Asylum"). For space reasons we will concentrate on only the first four of those five elephants.

There is, of course, some overlap among these five themes, and much of what is said here about Oxford also applies to Cambridge, the other UK "top ten" global player-an institution similar to Oxford in terms of intensive and expensive undergraduate teaching (via "supervisions" rather than "tutorials"), costly research activity (even more "big science" than in Oxford), and the socioeconomic background of the students (posh!). Parts of this essay relate to other elites such as University College London, Imperial, London School of Economics, Manchester, and Edinburgh. Put simply, if we want to maintain the lucrative export industry that is "UK higher education plc" (worth some $\mathcal{E 3}_{3}$ billion per annum to gross domestic product on top of UK higher education's ca. $£ 40$ billion general contribution within the economy), these flagship universities must be adequately funded. The whole national higher education brand depends on the continued success of these elite subbrands. Hence the presence of the elephants in the SCR needs to be addressed if we are to avoid the mediocre and moribund nature of higher education systems in other major European countries.

\section{Remaining World Class}

In 2004 the Oxford Centre for Higher Education Policy Studies (OxCHEPS) and the Ulanov Partnership costed Oxford, using the methodology developed in the United States for the National Association of College and University Business Officers "Cost of College Project" and hence allowing a direct comparison of metrics with Harvard, Princeton, and Berkeley. The essence of the OxCHEPS message was that Oxford needs another $£$ I50 million a year on top of its $£ 500$ million budget if it is to remain globally competitive. In the context of a halving of the taxpayer-funded "unit of resource" 